\title{
Missing links
}

Om korrespondancer mellem Edvard Munchs Skrik og Charles Darwins The Expression of the Emotions in Man and Animals

Hedin, Gry

Published in:

Kunst og Kultur

Publication date:

2011

Document version

Også kaldet Forlagets PDF

Citation for published version (APA):

Hedin, G. (2011). Missing links: Om korrespondancer mellem Edvard Munchs Skrik og Charles Darwins The Expression of the Emotions in Man and Animals. Kunst og Kultur, 94(3), 134-145. 


\section{Missing links}

\section{Om korrespondancer mellem Edvard Munchs Skrik og Charles Darwins The Expression of the Emotions in Man and Animals}

\author{
Abstract \\ Important correlations exist \\ between The Scream, the famous \\ painting by Edvard Munch, and a \\ late publication by Charles Darwin. \\ The natural sciences have long \\ been recognized as an important \\ context of the artworks of Munch, \\ but the fact that such references \\ imply that Munch took part in a \\ redefinition of man and his relation \\ to nature has only rarely been con- \\ sidered. Inquiring into this, the \\ article will situate Munch in this \\ context.
}

\section{Keywords}

Edvard Munch

Charles Darwin

Natural Sciences

The Scream

\section{Gry Hedin}

ghedin@hum.ku.dk

I de sidste tiår har flere Munch-forskere peget på ligheder mellem de videnskabelige studier af mennesket og Edvard Munchs kunst. Det galder også Munchs forste version af Skrik. Trods dette mangler der dog en analyse af den kontekst, der hermed relateres til billedet. Har Munch ikke bare fundet inspiration i naturvidenskaben, men forholdt sig til den omdefinering af mennesket som biologisk vosen, som blev gjort her, tilføjer det vosentlige nye dimensioner til billedet.

\section{Motivfællesskab}

Der er et stærkt motivfællesskab mellem Munchs figurskildring i Skrik (ill. 1 og 2) og den karakteristik af rædslen, man finder i den samtidige naturvidenskab. I Skrik er figurens ansigt således blegt, munden er åben, og øjnene er spilet op, øjenbrynene er løftet, der er antydet koncentriske rynker i panden og omkring den åbne mund, og afstanden mellem de tydeligt markerede næsebor indikerer, at de er udspilet. I en tekst, som Munch formulerede forud for Skrik, og som dannede grundlag for de tekster, han lod ledsage den grafiske version af billedet i bl.a. La Revue Blanche (ill. 3), supplerer han med karakteristika, der ikke umilddelbart lod sig fremstille visuelt. Jeg-fortælleren i den prosalyriske tekst beskriver således, hvordan en oplevelse af en blodig rød himmel ledsages af en følelse af at være træt til døden, af at skælve af angst og af at føle et skrig. ${ }^{1}$ Disse fysiologiske reaktioner beskrives af Darwin som karakteristiske for følelsen af rædsel. Man finder dem oplistet $\mathrm{i}$ tolvte kapitel i det idag noget oversete værk The Expression of the Emotions in Man and Animals. ${ }^{2}$ Bogen udkom i 1872, året efter The Descent of Man, og udmærker sig ved at være det værk, hvor Darwin mest indgående diskuterer konsekvensen af sin teori for opfattelsen 


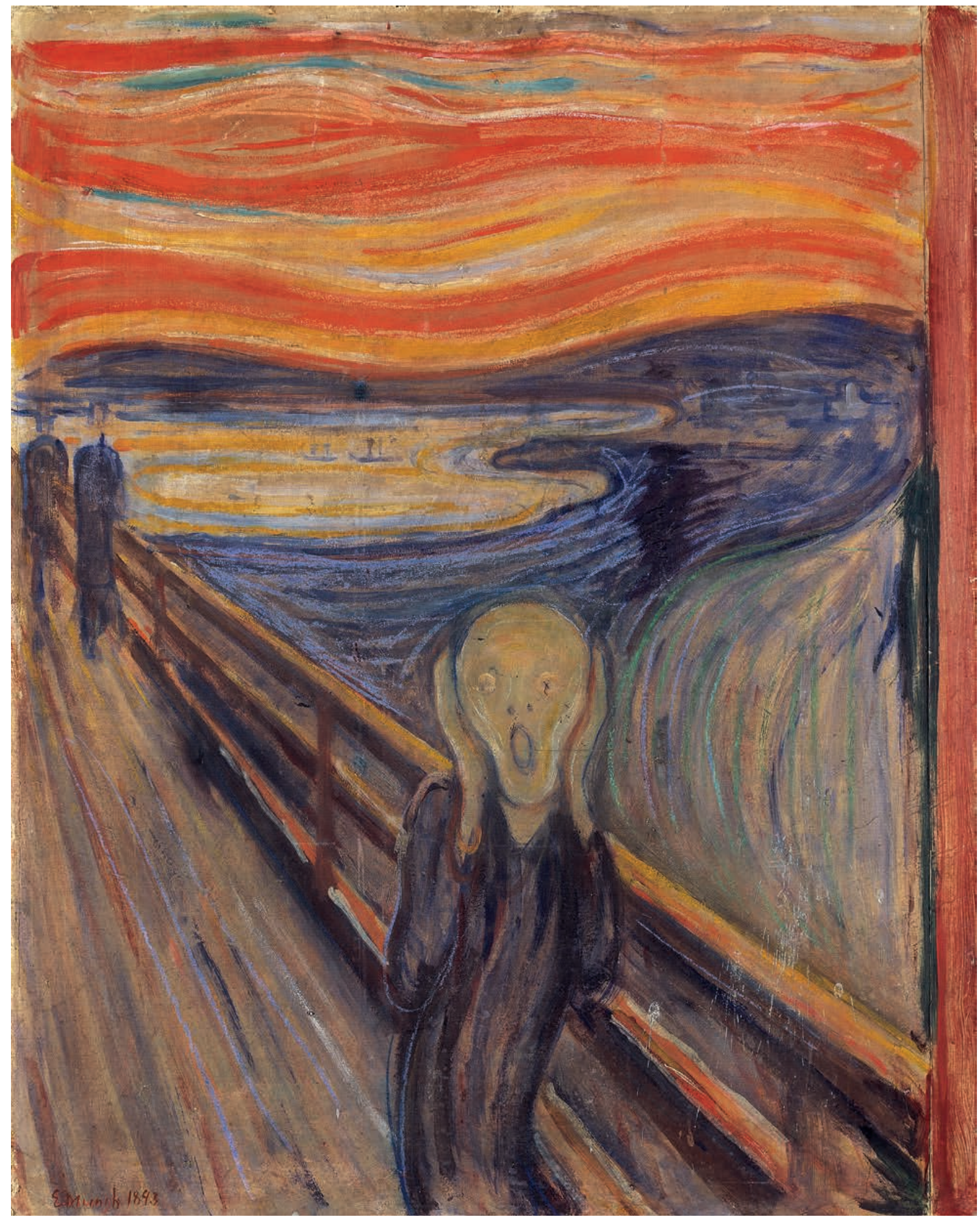

Ill. 1. Edvard Munch: Skrik, 1893. Tempera og farvekridt på pap, 91 x 73,5 cm. Nasjonalmuseet for kunst, arkitektur og design, Oslo. (C) Munch-museet/Munch-Ellingsen gruppen/BONO 2011 


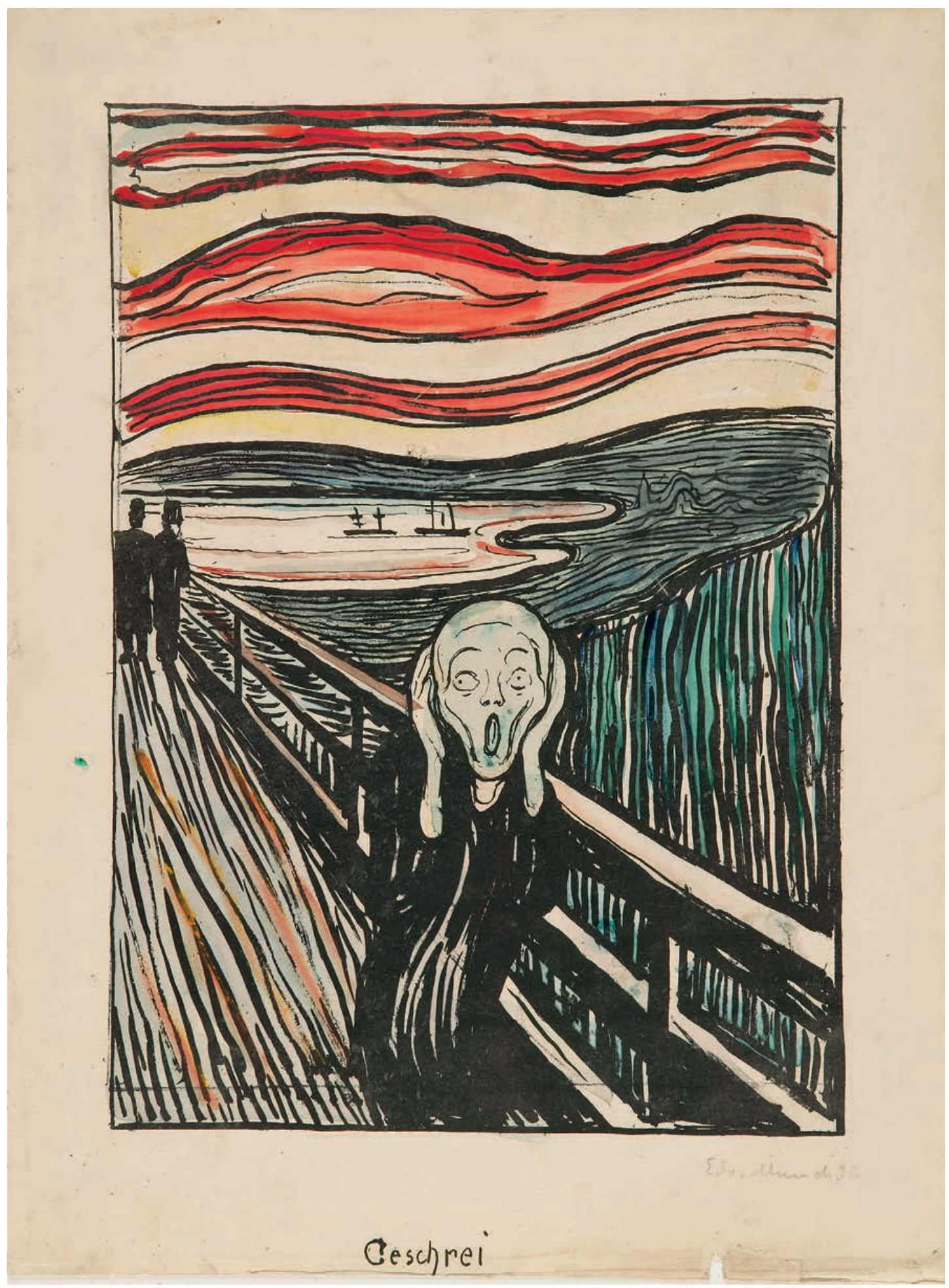

Ill. 2. Edvard Munch: Skrik, 1895. Litografisk stift og tusch, 355 x 254 mm. Munch-museet, Oslo. @ Munch-museet/ Munch-Ellingsen gruppen/BONO 2011 


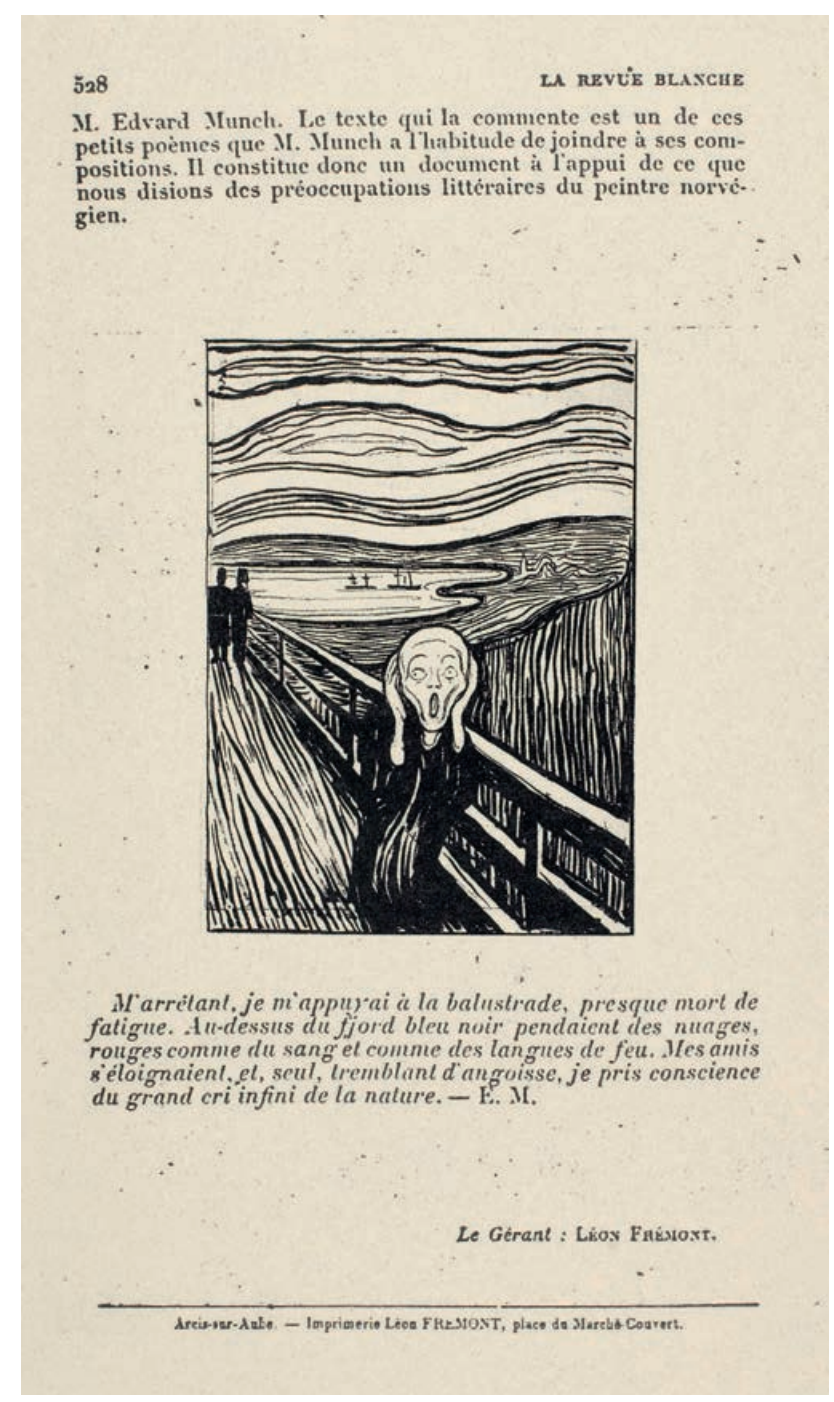

Ill. 3. Edvard Munch, Skrik, 1895. Gengivet s. 528 i La Revue Blanche bind IX 1895.

af mennesket. Bag undersøgelsen af rædslen ligger der hos Darwin en interesse for at udforske mennesket, når det truet på sin eksistens blotter sin 'indre natur'. En lignende interesse, vil jeg redegøre for, kendetegner Munchs arbejde med rædslen som motiv i Skrik.

Darwin illustrerede sin tekst med to xylografier og et heliografi, der var reproduceret på baggrund af fotografier fra forsøg med galvanisering af ansigtsmuskler udført af den franske læge Duchenne de Boulogne. Særligt heliografiet har ligheder med figurens ansigt i Skrik (ill. 4). ${ }^{3}$ Øivind Storm Bjerke har påpeget lighederne mellem Munchs gengivelse af figuren i Skrik og disse illustrationer, ${ }^{4}$ men også andre naturvidenskabelige beskrivelser af rædsel er blevet fremhævet for deres ligheder med Skrik. Det gælder tekster af de italienske læger Paolo Mantegazza og Angelo Mosso og af den danske læge Carl Lange. Arne Eggum har nævnt Langes bog Om Sindsbevogelser. Et psyko-fysiologisk Studie fra 1885, ${ }^{5}$ mens Shelley Wood Cordulack har fremhævet Mantegazza, der beskrev rædsel i Fisonomia e Mimica i 1881 og Mosso, der udgav en bog om rædsel, La Paura, i 1884. ${ }^{6}$ Mantegazza, Mosso og Lange udgav deres værker i kølvandet på Darwin og var i modsætning til ham læger af uddannelse. De diskuterede følelsesudtryk på et fysiologisk grundlag, om end der til Mantagazzas betragtninger knytter sig en antropologisk dimension. De beskriver grundlæggende rædslen i samme termer som Darwin og lægger som ham vægt på den rædselsslagnes træthed, bleghed, skælven, fokusering af blikket og så videre. Der, hvor de adskiller sig fra Darwin, er i deres forklaringer af, hvorfor den rædselsslagne reagerer, som han gør. Og det er her, det bliver interessant i forhold til Munch, for hvad foregår der i Munchs billede, rummer også det, ligesom de naturvidenskabelige tekster, en fortolkning af rædslen? Og hvordan forholder Munch sig i sit arbejde med dette motiv til den omdefinering af mennesket som biologisk væsen, som disse forfattere giver vidt forskellige bud på?

Før dette skal undersøges nærmere, er det værd at bemærke, at der ud over disse naturvidenskabelige værker er blevet peget på to litterære forlæg. Arne Eggum og Sigrid Fløttum Kristoffersen har fremhævet beskrivelsen af angst i Fjodor Dostojevskijs Raskolnikov og i Jobs bog, som Darwin i øvrigt citerer i sin tekst. ${ }^{7}$ Der er dog en detaljeringsgrad i Munchs karakteristik af rædslen, der ikke kan forklares udtømmende med henvisning til Jobs bog og Raskolnikov, men som svarer nøje til de beskrivelser, man finder i de naturvidenskabelige værker.

\section{Receptionen af Darwin i miljøet omkring Munch}

Blandt de fire forfattere til de naturvidenskabelige beskrivelser af rædsel udmærker Darwin sig som en 


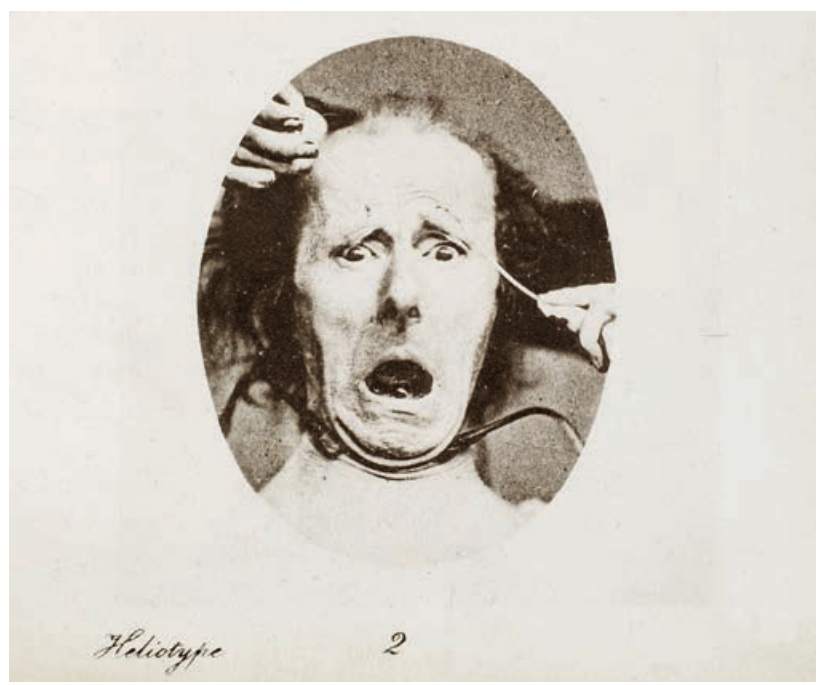

Ill. 4. Heliografi af Duchenne de Boulogne gengivet s. 300 i Charles Darwin: The Expression of the Emotions in Man and Animals, John Murray, London 1872.

skikkelse, der i modsætning til de andre var kendt i den almindelige offentlighed, og hvis teorier blev koblet til en omdefinering af mennesket. Darwins The Expression of the Emotions in Man and Animals var skrevet i et let tilgængeligt sprog og fik stor udbredelse på tværs af fag-og landegrænser. Den blev oversat til tysk, da den udkom i 1872 og til fransk to år efter, og var så populær begge steder, at den måtte genoptrykkes flere gange. I 1890 udkom en ny udgave redigeret af Darwins søn, Francis Darwin. ${ }^{8}$

I Norden var Darwins teori op gennem 1870erne og 80 erne blevet formidlet i tidens tværfaglige tidsskrifter, ofte som del af det moderne gennembruds politiske agenda, men interessen stoppede ikke her. Også i de sene 1880 ere og op gennem 90erne bragte tværvidenskabelige tidsskrifter som Tilskueren, Ny Jord og Samtiden artikler af og om Darwin side om side med tekster af blandt andre Knut Hamsun, August Strindberg, Ola Hansson og Herman Bang. Her optræder Darwin i en anden betydningsramme end det moderne gennembruds, idet han nu præsenteredes i selskab med tænkere som Schopenhauer, Nietzsche og Baudelaire. Fokus synes at være på Darwin som filosof og på de eksistentielle frem for samfundsmæssige aspekter af hans teori.

Også i Tyskland og Frankrig var interessen stor.
Tyskerne havde tidligt taget Darwin til sig, og hans teorier var blevet formidlet og fortolket af Ernst Haeckel, mens receptionen i Frankrig var præget af Jean-Baptiste Lamarcks beslægtede teori. ${ }^{9}$ Der var en fornyet interesse for Darwin blandt de forfattere, som Munch omgikkes med i Paris og Berlin, hvor han opholdt sig over længere perioder i de år, hvor han udviklede Skrik som motiv. Det gælder blandt andre August Strindberg, Jonas Lie, Ola Hansson og Stanislaw Przybyszewski. ${ }^{10}$ Der optræder i disse år også utvetydige referencer til Darwin blandt tidens billedkunstnere. I forhold til Munch er det særlig interessant, at Christian Krohg, der var i tæet kontakt med Munch i Kristiania, og Max Klinger, hvis værker Krohg og Munch begge var optaget af, åbenlyst refererede til Darwin. ${ }^{11}$ Der var også stor interesse for Darwin blandt franske kunstnere. Der var, som senest Richard Kendall har redegjort for, en opmærksomhed omkring netop Darwins The Expression of the Emotions in Man and Animals blandt kunstnere som Claude Monet og Edgar Degas, der havde Munchs interesse i de sene 1880 ere. ${ }^{12} \mathrm{Og}$ også symbolister som Odilon Redon, som Munch kan have stiftet bekendtskab med gennem Johan Rohde og J.F. Willumsen, var optaget af Darwin, som det blandt andet kom til udtryk i hans litografiske serie Les Origines.

Man har gættet på, at Darwins reproduktion af Duchennes fotografier var med til at gøre The Expression of the Emotions in Man and Animals populær i Frankrig. ${ }^{13}$ Der var en lang tradition på kunstakademierne for at undervise de studerende i menneskets anatomi og følelsesudtryk, og netop Duchennes billeder og Darwins bog var en del af undervisningen i anatomi på Ecole des Beaux-Arts i Paris. ${ }^{14}$ Ligesom Mantegazza og Mosso så Duchenne sig som del af denne tradition og opfordrede kunstnerne til at støtte sig til hans fotografier. ${ }^{15}$ Med Darwins reproduktion i heliografi blev et udpluk af Duchennes fotografier mangfoldiggjort $i$ en hel anden grad end det havde været muligt for Duchenne selv. ${ }^{16}$ I forhold til kredsen omkring Munch er det bemærkelsesværdigt, at interessen for Duchenne kan være blevet vakt gennem den berømte hysterilæge Jean-Martin Charcot. Duchenne havde frem til sin død i 1875 arbejdet tæt sammen med Charcot. ${ }^{17}$ Charcots 
eksperimenter, som demonstreredes under åbne forelæsninger på Hôpital de la Salpêtrière, havde vakt opsigt blandt franske kunstnere og digtere, såvel som blandt de tilrejsende skandinaver, herunder Strindberg. ${ }^{18}$

\section{Darwins omdefinering af mennesket}

Blandt de nævnte naturvidenskabelige værker om menneskets følelsesudtryk indtager Darwins The Expression of the Emotions in Man and Animals en særstatus. Bogen blev i lægevidenskabelige kredse betragtet som det værk, der havde åbnet for, at menneskets følelsesudtryk kunne studeres inden for de nye rammer, som naturvidenskaben siden midten af 1800-tallet havde arbejdet under. ${ }^{19}$ Darwin markerer selv bruddet i sin indledning. Her afviser han Duchennes forestilling om mennesket som fuldendt og skabt af Gud. Duchenne, refererer han, mener, at følelsesudtryk er uforanderlige og nedfældet i mennesket af en skaber. Ved at tilføre elektricitet, kunne ansigtsmusklerne ifølge Duchenne bringes til at tale følelsernes sprog for derved at afsløre sjælen. For Darwin derimod afslører Duchennes forsøg, at menneskets fysiologi og psykologi er i bestandig forandring, og at det blandt andet er evnen til at overleve livstruende situationer, der driver udviklingen. ${ }^{20}$

Darwin diskuterer udtrykket af rædsel inden for disse rammer og redegør for det hensigtsmæssige i den rædselsslagnes reaktioner. Han peger på, at der sættes forskellige overlevelsesmekanismer i gang, når et menneske trues på livet, som den rædselsslagne ikke har kontrol over. De er i vid udstrækning fælles for dyr og mennesker og røber, at mennesket er en ikke-privilegeret del af naturen. Det gælder udspilningen af øjnene og de løftede øjenbryn, der øger synsfeltet og skærper opmærksomheden. Tilsvarende sikrer en åben mund, at lyden fra et heftigt åndedræt ikke forstyrrer hørelsen. En åben mund indikerer således ikke nødvendigvis et skrig, men skaber fri passage for åndedrættet. ${ }^{21}$

Denne skærpelse af sanserne øger den rædselsslagnes overlevelseschancer, idet det bliver muligt for ham hurtigt at identificere faren. Andre reaktioner som angstskriget og den ufrivillige reaktion, at håret rejser sig, har derimod en afværgende funktion. Hårrejsningen, der får dyr til at se større ud, er dog hos mennesket blevet funktionsløs, et rudiment eller en påmindelse om de livsformer, som mennesket er efterkommer af. Angstskrigets afværgende funktion beskrives i kapitlet «Means of Expression in Animals», hvor Darwin trods kapiteloverskriften også drøfter menneskets forskellige typer af skrig. Angstskriget, mener han, kan have været den første lyd, en organisme har frembragt. ${ }^{22}$

Det er disse forklaringer og ikke beskrivelsen af rædslens fysiske udtryk, der gør Darwins redegørelse forskellig fra den, man finder hos Duchenne og de tre læger, Mantegazza, Mosso og Lange. Og det er dette, der skal vurderes i forhold til Munchs fortolkning af rædslen i Skrik. Selvom de tres værker var mindre udbredte end Darwins, var de ikke ukendte i kredsen omkring Munch. For eksempel havde Strindberg bøger af Mantegazza og Mosso i sit bibliotek, og Mosso nævnes af Hansson. ${ }^{23}$ Mantegazza, Mosso og Lange er enige med Darwin i, at mennesket ikke er en fuldstændig skabning, og at undersøgelsen af det skal foregå på et empirisk grundlag uden forudfattede forestillinger. De anerkender hver især det epokegørende i Darwins værk og støtter grundlæggende hans observationer og metoder. Men de tager også forbehold. Lange tvivler på bogens «evolutionistiske Retning» og peger på, at den har ledt særligt den engelske psykologi til «en Forsømmelse af den egenligt fysiologiske Analyse». ${ }^{24}$ Mosso mener tilsvarende, at Darwin ikke er fysiolog nok i sine undersøgelser. ${ }^{25}$ De tager begge afstand fra, at Darwin lod evnen til overlevelse være en determinerende faktor i forståelsen af menneskets følelsesudtryk. Mens Darwin er optaget af det hensigtsmæssige i, at kroppen reagerer, som den gør, er de optaget af det ofte uhensigtsmæssige i den menneskelige fysiognomi. For eksempel peger Mosso på det uhensigtsmæssige i, at den rædselsslagne skælver. Denne skælven, mener Mosso, øger ikke den rædselsslagnes muligheder for at overleve, men gør ham sårbar. Dette gælder også den rædselsslagnes overdrevne fokusering af blikket. På baggrund af enkle forsøg afviser han, at opmærksomheden øges. Han mener, at flere af den rædselsslagenes reaktioner skal forklares som fysiognomiske uhensigtsmæssigheder. ${ }^{26}$

De tre læger følger således Darwins opfordring til at revurdere mennesket som biologisk væsen, men de gav 
udforskningen af menneskets fysiognomi en drejning fra eksistens til mekanik. Darwins grundlæggende tese er, at mennesket er ustabilt. Det er i stadig udvikling med evnen til at overleve, tilpasse og forplante sig som dynamiske kræfter. Det viser sig tydeligt, når han i $\mathrm{Om}$ Arternes Oprindelse redegør for, hvordan det menneskelige øje er i stadig forandring fra blot at have været lysfølsomme celler, eller når han i Menneskets Afstamning og Parringsvalget beskriver, hvordan selv menneskets sjælsevner er ufuldstændige og underlagt en fortsat udvikling. ${ }^{27}$ Men mennesket, der hos Darwin er i konstant forandring, er hos lægerne mere ufuldstændigt og uhensigtsmæssigt end ustabilt. Der er den grundlæggende forskel på opfattelsen af mennesket som henholdsvis ufuldstændigt og ustabilt, at hvor det ufuldstændige kan beskrives, så undsiger det ustabile sig den udtømmende forklaring. Derfor finder man en udtalt forsigtighed hos Darwin omkring muligheden for at opnå en fuld forståelse af menneskets fysiologi og sjæleliv og omkring muligheden for, at mennesket nogensinde kommer til at forstå sig selv og sin oprindelse. Forsigtigheden er tydelig i hans metode og i måden, han synliggør sin metode gennem en udbredt brug af jegform i sin fremstilling. Herved tydeliggør han for læseren, hvordan han når frem til sine resultater, og han tydeliggør, at enhver iagttagelse er subjektivt funderet. Denne metode og refleksionen over mennesket som en ustabil størrelse er til stede i Munchs billede.

\section{Metodefællesskab}

Synliggørelsen af den empiriske metode og den udbredte brug af jeg-form er en argumentationsstruktur, som er fælles for The Expression of the Emotions in Man and Animals og Munchs første versioner af Skrik. Om der er tale om empirisme i videnskabelig forstand er i denne forbindelse uvæsentlig, det er måden den sætter sig igennem i argumentationen eller formsproget, i fortællestrukturen, der er vigtig. Dette metodefællesskab med Darwin findes i billedets formsprog såvel som i strukturen af den prosalyriske tekst til litografiet, her i den form den havde i det norske udkast, der lå til grund for den franske oversættelse i La Revue Blanche:

«Jeg gik bortover veien med to venner - så gik solen ned. Himmelen blev pludseli blodi rø. Jeg standset, lænet mig til gjæret træt til døden - over den blåsorte fjor og by lå blod og ildstunger. Mine venner gik videre og jeg sto igjen skjælvende af angest - og jeg følte det gik et stort uenneligt skrig gjennem naturen ${ }^{28}$

I teksten er der en tydelig jeg-form. Den starter med «Jeg gik», den fortsætter i «Jeg standset» og «jeg sto» for at kulminere $\mathrm{i}$ «jeg følte det gik et stort uenneligt skrig gjennem naturen». I billedet er der et formsprog, der slægter på den litterære jeg-form med placeringen af den frontale figur forrest i billedplanet, en spejling af den typiske beskuerposition foran billedet såvel som af kunstnerens placering under udførelsen af værket. Også teknisk er den åbenlyse materialebearbejdning, der blotlægger kunstnerens arbejdsproces, beslægtet med den litterære jeg-form. ${ }^{29}$

Jeg-formen i Munchs tekst er i forskningen blevet koblet til den nordiske prosalyrik med Vilhelm Krag og Johannes Jørgensen som mulige forbilleder, ${ }^{30}$ mens jeg-formen i relation til spørgsmålet om hvem, der skriger, er blevet set i forhold til samtidens interesse for synæstesi, idet jeget ikke skriger, men føler et skrig. ${ }^{31}$ Anvendelsen af jeg-formen i naturvidenskaben er en oplagt tredje mulighed, der kan supplere de to. Den er central for retorikken og den blotlagte metode i Darwins værker, ligesom den er det i andre centrale naturvidenskabelige værker fra perioden. ${ }^{32}$ Munchs jeg-form har sammen med tidens litteratur en kontekst her.

Jeg-formen er central hos Darwin ikke bare for hans retorik og ønske om at engagere læseren, men som en uundværlig del af den metode og filosofi, han bygger på. Han bruger jeg-formen til at synliggøre sin empiriske metode og blotlægge for læseren, hvordan han når frem til sine resultater, og til at markere at hans teori er en hypotese på baggrund af empiriske undersøgelser af individuelle organismer. ${ }^{33}$ Herigennem understreger han både, at undersøgelsernes genstande er ustabile, og at enhver observation er forankret i et subjekt. I The Expression of the Emotions in Man and Animals veksler undersøgelsernes genstande mellem at være langt borte og tæet på. Han refererer til 
observationer af følelsesudtryk registreret hos de indfødte i Australien og Sydafrika og hos engelske sindssyge, og til observationer af sig selv og sine nærmeste. Observationerne veksler mellem at være anekdotiske iagttagelser eller observationer af eksperimenter gjort af andre, og at være observationer gjort af ham selv blandt andet på sig selv. Denne vekslen er tydelig i afsnittet om rædsel, hvor Darwin redegør for de ufrivillige bevægelser, der følger med det at skælve:

"I have caught myself giving a little involuntary shudder at a painful thought, and I distinctly perceived that my platysma contracted; so it does if I simulate a shudder. I have asked others to act in this manner; and in some the muscle contracted, but not in others.» ${ }^{34}$

Darwin beskriver i jeg-form først en selviagttagelse, efterfølgende et selveksperiment, og sidst hvordan han har opfordret andre til at udføre eksperimentet. Jegformen bruges således, både når der er tale om selvgjorte observationer, og når der argumenteres på basis af andres observationer, og den bruges til at differentiere mellem dem. I afsnittet om rædsel veksler Darwin mellem denne jeg-form og beskrivelser i en objektiv form. Rædslens højdepunkt beskrives for eksempel uden, at observatøren giver sig til kende:

«As fear rises to an extreme pitch, the dreadful scream of terror is heard. Great beads of sweat stand on the skin. All the muscles of the body are relaxed.» 35

I beskrivelsen af rædselsskriget er det derfor usikkert, hvem der er det iagttagende subjekt, og hvem der er det iagttagede objekt. Altså hvem det er, der hører skriget, og hvem det er, der skriger.

Denne usikkerhed er også fremtrædende i teksten til Munchs billede. Munch skriver trods jeg-formen ikke, at skriget skriges eller høres. Han skriver, at skriget føles, således at det bliver usikkert, hvor skriget kommer fra. Har Munch læst Darwins tekst, er der ikke nødvendigvis tale om en fejllæsning af, hvorvidt den rædselsslagne skriger eller hører et skrig. Usikkerheden sætter gang i en række forskydninger, som er afgørende for billedet. Den sætter gang i en forskydning fra maler-iagttager til den passive beskuer, som foran billedet netop ikke hører, men - såfremt han identificerer sig med figuren - føler et skrig. Dette skrig, skriver Munch, går gennem naturen. Her sker samme forskydning, idet den natur, som skriget går igennem, både kan være naturen omkring det afbillede menneske eller naturen i mennesket. På samme måde kan sceneriet i baggrunden være det, der fremkalder sindsstemningen, eller en projektion af den rædselsslagnes sindsstemning. De forskydninger mellem natur og menneske, der gør dikotomien usikker, er interessante i forhold til Darwins påpegning af, at den rædselsslagnes reaktioner er uden for bevidsthedens kontrol og fælles for så forskellige organismer som mennesker, fugle og fisk. Det gælder ud over hårrejsningen også skriget. ${ }^{36}$ Munchs billede er læst på denne vis en visualisering af, hvordan det menneskelige, jeget, i rædslens øjeblik kobles fra, således at mennesket bliver 'ren' natur renset for alle individuelle træk. Det, at jeg-formen er til stede for at blive opløst, er interessant i forhold til Darwins redegørelser for menneskets følelsesudtryk som ikke blotte beskrivelser af fysiske og psykiske symptomer, men som argumenter for en ny forståelse af forholdet mellem krop og sind, og menneske og natur. I forhold til Munchs billede er det interessant, at Darwin - som Jonathan Crary har påpeget det - herved giver ansigtet en ny betydning. Hos Darwin er ansigtet splittet mellem at være et simultant udtryk for en organismes fysiske og psykiske funktioner, og i dets relative ulæselighed at være en markering af den selvkontrol eller mangel på samme, der ligger implicit i den sociale konstruktion af det normative individ. ${ }^{37}$

Munchs billede rummer læst på denne vis ikke blot en opløsning af dikotomien menneske og natur, men også dikotomien normalitet og galskab. I tabet af selvkontrol ligger en kompromittering af mennesket som socialt acceptabelt individ, en problematisering af identifikationen med figuren i billedet, der bekræftes af den tidlige reception af maleriet. ${ }^{38}$ Til stede hos Darwin ligger forestillingen om, at følelsesmæssige reaktioner optræder stærkere i individer, der mangler vilje og selvkontrol. Det gælder sindssyge, børn og vilde - og til en 
vis grad kvinder. En af illustrationerne i Darwins afsnit om rædsel viser en sindssyg kvinde, hvor hårrejsningen, på grund af hendes lette påvirkelighed, er blevet en permanent tilstand. ${ }^{39}$

Jeg-formen og dens opløsning gør oplevelsen af værket til et grænseoverskridende eksperiment. I synliggørelsen af metoden ligger der en appel til modtageren om at træde ind som medundersøger. Figuren ved rækværket både illuderer og illuderer ikke Munch selv, oplevelsen af rædsel kan både være en selviagttagelse, et selveksperiment eller blot et tankeeksperiment, der kan deles med beskueren, en form, der ligeledes er hyppig hos Darwin. Men det eksperiment eller den vivisektion, som beskueren via billedet begiver sig ind i, er ikke ufarlig. Darwin opfordrede med sin jeg-form til, at vi undersøger os selv og verden omkring os, en opfordring som Munch tog op, men som hos ham kommer til at indebære et tab af selvkontrol. Munch tager således stilling til de samme grundlæggende spørgsmål som Darwin med en konsekvens, der ikke er mindre radikal end den, man finder hos videnskabsmanden.

\section{Den narrative ramme om Skrik}

I rædselsøjeblikket trues mennesket på sin eksistens. Opløsningen af dikotomien menneske og natur indebærer både et tab af kontrol og et møde med døden. Dette gælder både i Munchs og Darwins fortolkning af rædslen som en eksistentielt betydningsfuld situation. Ses Skrik i dette perspektiv bliver rædslens karakteristika som de udspilede øjne, den åbne mund, blegheden osv. tegn, der er aflæselige inden for en større fortælling om overlevelse og liv og død. Undersøges den narrative ramme, som Munch indsatte billedet i de første år, han udstillede det, og undersøges de tekster, som han skrev i tilknytning til billedets prosadigt, bliver dette tydeligt.

Døden er til stede i Munchs billede såvel som i den prosalyriske tekst. Figurens ansigt, er det blevet bemærket, minder om en død persons eller et kranium, ${ }^{40}$ og i teksten fremmanes dødens nærvær i beskrivelsen af, at den rædselsslagne er "træt til døden», at himlen er «blodi rø», og at der over den blåsorte fjord og by ligger «blod og ildstunger». Da Munch udstillede maleriet første gang understregedes dette, ligesom der kobledes til endnu et vigtigt element i en eksistentiel ramme: kærlighed og forplantning. Skrik blev i Berlin i 1893 udstillet under titlen Verzweiflung som det sidste billede i serien Die Liebe efter titler som SommernachtsTraum, Kuss, Liebe und Schmerz, Das MadonnaGesicht og Eifersucht. Skrik var således ifølge kataloget det sidste billede i en tragisk fortælling om kærlighed, der ikke ender i samhørighed og forplantning, men i jalousi og fortvivlelse. ${ }^{41}$ Munch tilføjede flere billeder til serien de næste år, og i Berlin i 1902 fordelte han dem over fire vægge. I forhold til Darwin er det interessant, at han her valgte de fire overskrifter: «Keimen der Liebe“, «Blühen und Vergehen der Liebe», «Lebensangst» og «Der Tod». Overskrifterne rummer begreber som kim og blomstring, der refererer til naturens livsprocesser for dermed at sidestille menneskets forplantning med processer i naturen. Skrik var ifølge kataloget det sidste billede på væggen "Lebensangst». ${ }^{42}$

Død og forplantning er som hinandens modsætninger de dynamiske kræfter i Darwins fortælling, der udspiller sig over et vidtstrakt tidsperspektiv. Dette tidsperspektiv benævnes af Munch som «de tusinde slægtled» i en af de tekster, der knytter sig til denne serie billeder, det såkaldte Saint-Cloud manifest skrevet omkring nytår 1890:

«Jeg skulde gjøre noget - begynde på noget. Det skulde gribe andre som det nu greb mig.

Jeg skulde fremstille to i deres livs helligste øieblik - hvor de var grebet af den magt der tvinger stærkere end alt andet - der har rosens farve men er stærkere end døden - I det øieblik man ikke er sig selv - men kun et af de tusinde slægtled - der forplanter slægten.» ${ }^{43}$

Også her findes der en fascination af mennesket som del af naturens processer og en fortælling om mennesket der, som en ikke-privilegeret del af naturen, er underlagt naturens vilkår. I denne tekst er kærligheden som forplantning dødens modsætning. Ud over valget af begrebet «forplanter», der har biologiske undertoner, er det betydningen af det enkelte menneskes trang til forplantning i forhold til «de tusinde slægtled», der er 
interessant i forhold til Darwins fortælling. Teksten har en positiv undertone, forplantningen er «stærkere end døden», men i serien, som den blev vist i Berlin i 1893, fik fortællingen en drejning, der betonede det tragiske aspekt af Darwins fortælling, det at kun enkelte frø sætter nye frø, mens mange går til spilde. ${ }^{44}$

I 1892 da Munch forfattede den første prosalyriske tekst, der skulle knyttes til Skrik, optræder der på de sider, der går forud en tilsvarende fascination af mennesket som underlagt livets generelle principper. Dette er ikke tidligere blevet diskuteret i forhold til Skrik. Dateret Nizza 8/1 92 beskriver Munch sjælen som en livsspire eller livsånde, og han beskriver, hvordan alle stoffer i naturen veksler:

«Denne evne - til at holde et legeme sammen - at bringe stoffene i udvikling - livsånden / hvor bliver den af - / Intet forgår - man har intet exempel derpå / i naturen - / Legemet som dør - forsvinder ikke - stoffene / går fra hverandre - omsættes - / Men livsånden hvor bliver den a - / Hvor det kan ingen $\mathrm{si}$ » 45

Munch reflekterer over en central problemstilling inden for biologien, stoffernes vekslen og omdannelse i naturen. Det er interessant, at han i forlængelse af disse refleksioner, efter at have kritiseret kristendommen for at være fanatisk, tager polemisk stilling til samtidens naturvidenskab:

«At påstå idet heletaget noget / om hvad der kommer efter døden er dumt / Den var i forbindelse med den store bølge som gik over verden realismen / Ting existerte ikke uten de kunde påvises, forklares skematisk eller fysisk /- maleriet og literaturen var blit / det man så for øiet eller hørte med / ørene - det var skallet af naturen - / Man hadde git sig ro med de store opdagelser man havde gjort / - man tænkte ikke på at jo flere
/ opdagelser jo større gåder og / flere gåder at løse - man havde / fundet bakterier - med hvoraf består de igjen - Det mystiske vil altid exi[s]tere blir / jo mere der opdages - jo mere vil der bli af uforklarlige ting» 46

Det er på de følgende sider, at Munch under dateringen Nizza 21/1 92, altså blot to uger efter, skriver det første udkast til den prosalyriske tekst til Skrik.

På basis af de to tidlige versioner af Skrik, såvel som af Munchs personlige noter og den narration, som han tydeliggjorde for offentligheden gennem udstillinger og i udstillingskataloger kan Skrik ses som Munchs meget personlige italesættelse af spørgsmål, som var centrale indenfor naturvidenskaben. Der er et stærkt motivfællesskab mellem Munchs Skrik og Darwins beskrivelse af rædsel, men der er også et slægtskab i metoden og i fortolkningen af rædslen som en eksistentiel betydningsfuld situation. Dette vidner om, at der ikke bare er tale om, at Munch fulgte opfordringen fra fysiologer som Duchenne, Mantegazza og Mosso til at lade naturvidenskaben guide kunstnerne i deres fremstilling af følelsesudtryk. Han har derimod taget aktivt stilling til de eksistentielle spørgsmål, der lå bag tidens udforskning af rædslen.

Munch forholder sig med Skrik til nogle af de grundlæggende problematikker, som gjorde de brud, der var sket inden for naturvidenskaben aktuelle for den enkelte. Han fortolker på meget selvstændig vis menneskets status som en ikke-privilegeret del af naturen, der er underkastet processer, det ikke har fuld kontrol over. Munch forholdt sig således til en vigtig kontekst i tiden. En kontekst som det er værd at inddrage ikke bare i forhold til visuelle ligheder og som et reservoir af billeder og beskrivelser, men som en mangesidig og uensartet kontekst som hver enkelt videnskabsmand eller kunstner ved at forholde sig selvstændigt til kunne bidrage til tidens omdefinering af mennesket. 


\section{NOTER}

1 Teksten optræder første gang i en notesbog dateret 22. januar 1892 (T 2760) og i revideret form på en skitse til billedet Fortvilelse (T 2367). Hans-Martin Frydenberg Flaatten, «Skrik som ikon og dikt», Edvard Munchs Livsfrise. En rekonstruksjon av utstillingen hos Blomqvist 1918. Munch-museet, Oslo 2002, s. $67-69$.

2 Betegnelsen rædsel bruges i den samtidige videnskab synonymt med frygt og skræk. Der er også en tendens til at bruge rædsel og angst som synonymer uden skelnen til, om rædslen har en genstand eller er af mere ubestemt karakter. Darwin bruger betegnelsen "fear», når individet trues på livet og "terror» eller «horror», hvor et individ sympatiserer med en anden, hvis liv er truet. Charles Darwin, The Expression of the Emotions in Man and Animals, John Murray, London 1872, s. 289-307.

3 I de tre billeder registreres den skrækslagnes udspillede øjne og åbne mund, og hvordan der dannes koncentriske rynker i panden og omkring munden. Disse koncentriske rynker, der står tydeligere frem på xylografierne end på heliografiet, optræder i maleriet som lyse linjer og på litografiet som mørke linjer. Duchenne udførte sine forsøg i 1850erne, hvor det at gengive følelsesudtryk var vanskeligt pga. fotografiets lange eksponeringstid. Ved gennem elektroder at tilføre en jævn strøm var det muligt for Duchenne at fremkalde forskellige følelsesudtryk og udstrække dem over så lang tid, at de kunne registreres fotografisk. Phillip Prodger, Darwin's Camera. Art and Photography in the Theory of Evolution, Oxford University Press 2009, s. 81-82.

4 Øivind Storm Bjerke, "The Scream as image of a 'scream'», Kunst og Kultur, nr. 3, 2007, s. 180-82.

5 Arne Eggum, Edvard Munch. Livsfrisen fra maleri til grafikk, J.M. Stenersens Forlag, Oslo 1990, s. 231-32.

6 Shelley Wood Cordulack, Edvard Munch and the Physiology of Symbolism, Fairleigh Dickinson University Press 2002, s. 56.

7 Eggum, op. cit., s. 234-35 og Sigrid Fløttum Kristoffersen, «Jobs skrik? Et bidrag til tolkningen av Edvard Munchs maleri», Kunst og Kultur, nr. 1, 2000, s. 52. Munch nævner i 1892 i et brev, at netop Raskolnikov og biblen er i hans lille bibliotek. Ibid., s. 52.

8 Andet oplag af den tyske udgave kom i 1874, mens den tryktes igen i 1877 som del af en udgivelse af Darwins samlede værker. Andet oplag af den franske udgave tryktes i 1877. Udgaven fra 1890 blev ikke oversat til tysk, men udkom på fransk samme år. Bogen blev ikke oversat til dansk, norsk eller svensk.

9 Alfred Kelly, The Descent of Darwin. The Popularization of Darwinism in Germany 1860-1914, University of North Carolina Press, Chapel Hill 1981, s. 5 og Patrick Tort, «The Interminable Decline of Lamarckism in France», The Reception of Charles Darwin in Europe, vol. II, Continuum International Publishing Group Ltd, London 2008, s. 330.

10 Det skal fremhæves, at Przybyszewski i 1894 nævner Darwin i en udstillingsomtale, hvor Skrik fortolkes. Stanislaw Przybyszewski, «Psychischer Naturalismus», Freie Bühne, Heft 2, Februar 1894, s. 151.

11 Marit Ingeborg Lange, "The young Munch. Max Klinger's impact on his imagery", Kunst og Kultur, nr. 3, 2007, s. 161-73 og Marsha Morton, «'Impulses and Desires'. Klinger's
Darwinism in Nature and Society", Nineteenth-Century Art Worldwide, vol. 2, issue 2, Spring, 2003, upagineret.

12 Richard Kendall, «Monet and the Monkeys. The Impressionist Encounter with Darwinism», Endless Forms. Charles Darwin, Natural Science and the Visual Arts, Yale University Press, New Haven and London 2009, s. 302-16.

13 Joy Harvey, «Darwin in a French Dress. Translating, Publishing and Supporting Darwin in Nineteenth-Century France», The Reception of Charles Darwin in Europe, op. cit., s. 367.

14 Anthea Callen henviser til Mathias Duvals undervisning på Ecole des beaux-arts i Paris. Duval var professor fra 1873 til 1903. Darwins og Duchennes studier af rædsel nævnes i Duvals lektionsbeskrivelser, såvel som af Alexis Lemaistre, der studerede her. Anthea Callen, «The Body and Difference. Anatomy training at the Ecole des Beaux-Arts in Paris in the later nineteenth century", Art History, Special Issue, vol. 20, no. 1, March, 1997, s. 40,59 .

15 Duchennes fotografier var oprindeligt reproduceret $\mathrm{i}$ hans bog Mécanisme de la physionomie humaine ou analyse électro-physiologique de l'expression des passions, Jules Renouard, Paris 1862, der indeholdt en tredje sektion rettet specielt mod kunstnere. Angelo Mosso, Fear, Longmans, Green, and Co. 1896, s. 15-16 (oversættelse af Angelo Mosso, La Paura, Treves, Milano 1884) og Paolo Mantegazza, Physiognomy and Expres sion, The Contemporary Science Series, London [1890], (oversættelse af Paolo Mantegazza, Fisionomia e Mimica, Fratelli Dumolard, Milano 1881).

16 Før Darwins værk udkom, var der kun begrænset adgang til Duchennes fotografier. De 84 originale fotografier i Duchennes bog var klæbet ind, en bekostelig proces, der gjorde, at bogen blev trykt $\mathrm{i}$ et meget begrænset oplag.

17 Irwin M. Siegel, "Charcot and Duchenne. Of Mentors, Pupils, and Colleagues", Perspectives in Biology and Medicine, vol. 43, no. 4,2000 , s. $541-47$

18 Rodolphe Rapetti mener, at Munch kan have været til stede. Rodolphe Rapetti, «Munchs møte med den franske kritikken: 1893-1905», Munch og Frankrike, Munch-museet, Oslo 1991, s. 25 .

19 Mosso, op. cit., s. 9-10 og Mantegazza, op. cit., s. 20-21.

20 Darwin, op. cit., s. 11-12.

21 Darwin, op. cit., s. 278, 281-83.

22 Darwin, op. cit., s. 84-85.

23 Hans Lindström har registreret, at Strindberg i det bibliotek, som blev gjort op i 1892, havde en fransk udgave af Mossos bog om rædsel og Mantegazzas L'amour dans l'humanité. Af Darwin havde han Menniskans härledning och könsurvalet og tre bind af Charles Darwins liv og breve. Hans Lindström, Strindberg och böckerna, Svenska Litteratursällskapet, Uppsala 1977, s. 53, 66, 67, 76. Hansson citerede Mosso i sit essay om Poe ifølge Cordulack, op.cit., s. 53. Cordulack og Eggum mener, at populariteten af Langes bog taler for, at Munch kan have haft kendskab til den. De peger dog ikke på direkte referencer til Lange i kredsen omkring Munch. Cordulack, op. cit., s.11, 27 og Eggum, op. cit., s. 231-32. 
24 Carl Lange, Om Sindsbevcegelser. Et psyko-fysiologisk Studie, Jacob Lunds Forlag, Kjøbenhavn 1885, s. 36-37.

25 Mosso, op. cit., s. 176.

26 Mosso, op. cit., s. 176-78.

27 Charles Darwin, Om Arternes Oprindelse ved Kvalitetsvalg eller ved de heldigst stillede Formers Sejr i Kampen for Tilvorelsen, oversat af J.P. Jacobsen, Forlaget af den Gyldendalske Boghandel, Kjøbenhavn 1872, s. 235-36 og Charles Darwin, Menneskets Afstamning og Parringsvalget, oversat af J.P. Jacobsen, Forlaget af den Gyldendalske Boghandel, Kjøbenhavn 1874, s. $102-03$.

28 Citeret efter teksten på: Edvard Munch, Fortvilelse, 1891-92, Munch-museet, T 2367. Tekst som Munch har gennemstreget er udeladt. Den første version af teksten, som findes i Munchs notesbog (T 2760) lyder:

«Jeg gik bortover veien med to venner - solen gik ned

- Himmelen blev pludselig blodi rød

- Jeg følte som et pust af vemod -

Jeg stanset, lænede mig til gjærdet træt til døden så utover de flammende skyer som blod og sværd over den blåsvarte fjord og by -

- Mine venner gik videre - jeg stod der skælvende af angst - og jeg følte som et stort uendeligt skrig gjennem naturen -»

29 Erik Mørstad betoner det gensidige forhold mellem Munchs billeder og litterære tekster. Dette er interessant i forhold til, at Munch vælger et billedkunstnerisk modstykke til den litterære jeg-form og omvendt. Erik Mørstad, «Edvard Munchs Livsfrise: struktur, kontekst og kritikk», Kunst og Kultur, nr. 3, 2004, s. 129.

30 Flaatten, op. cit., s. 70-73.

31 Bjerke, op. cit., s. 177.

32 Et centralt og på samme måde mønsterskabende eksempel er Claude Bernards Introduction à l'étude de la médecine expérimentale fra 1865.

33 Gillian Beer, Darwin's plots. Evolutionary Narrative in Darwin, George Eliot and Nineteenth-Century Fiction, Third Edition, Cambridge University Press 2009, s. 251-54.
34 Charles Darwin, The Expression of the Emotions in Man and Animals, John Murray, London 1872, s. 303.

35 Darwin, op. cit., s. 292.

36 Darwin, op. cit., s. 84, 95.

37 Jonathan Crary, Suspensions of Perception. Attention, Spectacle, and Modern Culture, The MIT Press 1999, s. 99.

38 Gry Hedin, «Edvard Munch og den samtidige psykologi», Edvard Munch og Danmark, Ordrupgaard 2009, s. 33-36. Receptionen bekræftes på dette punkt af en indskrift øverst på billedet, der har været omgæret med en del mystik. Her har en ukendt person i 1890erne skrevet med blyant: «kan kun være malet af en gal mand». Gerd Woll, Edvard Munch Complete Paintings, Thames \& Hudson 2009, s. 315. En sådan kompromittering diskuterer Gillian Beer i sin analyse af, hvordan engelske forfattere fandt inspiration netop i Darwins beskrivelse af rædsel. Beer op. cit. s. 220.

39 Darwin, op. cit., s. 13, fig. 19.

40 Reinhold Heller, Edvard Munch. The Scream, Penguin Press, London 1973, s. 90 og Robert Rosenblum, «Introduction", Edvard Munch. Symbols \& Images, National Gallery of Art, Washington 1978, s. 8.

41 Edvard Munch. Gemälde-Ausstellung, Unter den Linden 19, Berlin 1893. At det var Skrik, der var udstillet under titlen «Verzweiflung» fremgår af Przybyszewskis omtale af udstillingen. Przybyszewski, op. cit., s. 153-54.

42 Ausstellung der Sezession. Katalog der fünften Kunstausstellung der Berliner Secession, Berlin 1902.

43 Citeret efter „Et utvalg av Edvard Munchs nedtegnelser i Frankrike“, Sissel Biørnstad og Arne Eggum (red.), Munch og Frankrike, Munch-museet, Oslo 1991, s. 345.

44 Beer, op. cit., s. 107.

45 Dagbogsoptegnelse, Munch-museet, Oslo, T2760, s. 54r.

46 Ibid., s. 54v. 